\title{
STRATEGI PENGEMBANGAN EKOWISATA MELALUI PENINGKATAN PARTISIPASI MASYARAKAT, STUDI KASUS KOMUNITAS KELURAHAN KALIMULYA KOTA DEPOK
}

\author{
Ecotourism Development Strategy through Increasing Community Participation, Case Study of \\ Urban Communities Kalimulya in Depok City
}

\section{Eva Kurniasari 1, Ernan Rustiadi ${ }^{2}$, dan Fredian Tonny ${ }^{3}$}

1 Staff Dinas Kebersihan dan Pertamanan Kota Depok. E-mail: mpdipb@hotmail.com

2 Staff Pengajar Departemen Ilmu Tanah. Fakultas Pertanian IPB.

E-mail:ernan@indo.net.id

${ }^{3}$ Staff Pengajar Departemen Sains Komunikasi Pengembangan Masyarakat. Fakultas Ekologi Manusia IPB E-mail: frediantonny@yahoo.com

\begin{abstract}
Since Depok relatively has limited natural resources, creativities and innovation are needed to develop local potential, such as tourism. Several potential tourism objects are located along Ciliwung Riverside. Moreover, this area was also included in the nature area development plan (Rencana Rinci Tata Ruang Bagian Wilayah Kota VIII Sukmajaya for plan development of 2013. The purpose of this research is to determine the level of community participation and potential development of social and economic activities, and also to analyze existing policies related to tourism development in Depok City. Methods used were interviews, observation and questionnaire. Stratified random sampling was applied to 30 respondents grouped by the education level and the work type. Data obtained were tabulated and analyzed descriptively by chi square. Formulation of strategies and policies for the development of ecotourism programs in this study were analyzed using the Analytical Hierarchy Process (AHP). Results showed that the level of community participation in research location was on the first ladder of Non-Participation and the second ladder of Tokenism on Arnstein's theory. Formulations of tourism development strategy are focused in enhancing the society capacity, regional arrangements, financing, infrastructure development, institutional development and also marketing.
\end{abstract}

Keywords: Ecotourism, Community Participation, Depok City

\begin{abstract}
ABSTRAK
Sumberdaya alam di Kota Depok relatif terbatas sehingga diperlukan kreativitas dan inovasi untuk mengembangkan potensi lokal, misalnya pariwisata. Beberapa obyek wisata yang berpeluang untuk dikembangkan menjadi sarana rekreasi berada di daerah sempadan Sungai Ciliwung, yang berdasarkan Rencana Rinci Tata Ruang Bagian Wilayah Kota VIII Sukmajaya pada rencana pemanfaatan Tahun 2013 merupakan salah satu wilayah rencana pengembangan nature area. Penelitian bertujuan untuk mengetahui tingkat partisipasi masyarakat, jenis kegiatan sosial dan ekonomi yang dapat mendukung ekowisata, serta menganalisis proses kebijakan yang sudah ada terkait dengan pengembangan ekowisata di Kota Depok. Metode penelitian dilakukan dengan wawancara, observasi dan kuesioner. Sampling dilakukan secara purposive pada 30 responden yang dikelompokkan berdasarkan tingkat pendidikan dan jenis pekerjaan. Data kemudian ditabulasi dan dianalisis secara deskriptif serta diuji dengan chi square. Perumusan strategi dan kebijakan guna pengembangan program dilakukan menggunakan analisis Analytical Hierarchy Process (AHP). Hasil penelitian menunjukkan bahwa tingkat partisipasi masyarakat di lokasi penelitian berada pada tangga pertama Non Participation dan tangga kedua Tokenism berdasarkan Teori Arnstein. Rumusan strategi pengembangan kawasan ekowisata diprioritaskan pada peningkatan kapasitas masyarakat, penataan kawasan, pembiayaan, pengembangan sarana prasarana, pengembangan kelembagaan serta pemasaran.
\end{abstract}

Kata kunci: Ekowisata, Partisipasi Masyarakat, Kota Depok 


\section{PENDAHULUAN}

\section{Latar Belakang}

Sungai Ciliwung merupakan salah satu sungai di Jawa Barat yang seringkali menimbulkan permasalahan lingkungan. Hal ini dikarenakan pengelolaan yang salah terhadap Daerah Aliran Sungai (DAS) sehingga mengurangi fungsi sungai sebagai pengatur tata air. DAS Ciliwung sebagaimana telah diketahui merupakan bagian dari wilayah tanggung jawab pemerintah dan masyarakat yang dilintasi oleh Sungai Ciliwung.

Kota Depok merupakan salah satu kota yang dilintasi oleh Sungai Ciliwung, sungai ini melintasi Kota Depok dari Selatan ke Utara sepanjang $24 \mathrm{~km}$ dan luas sempadan 100 meter. Hasil identifikasi sumber pencemar Sungai Ciliwung di Kota Depok tahun 2006 ditemukan bahwa masyarakat di sempadan sungai melakukan pembuangan sampah di tepi Sungai Ciliwung. Selain itu juga terdapat empat titik pembuangan limbah pabrik tahu, timbunan sampah dari wilayah perkebunan sebanyak tiga titik, pembuangan limbah domestik dari perumahan sebanyak tiga titik, dan pencemaran limbah domestik.

Berdasarkan perencanaan Kota Depok yang tertuang dalam Perda No. 12 Tahun 2001 tentang Rencana Tata Ruang dan Wilayah tersebut maka Pemerintah Kota Depok perlu mengembangkan konsep pengelolaan yang mempertimbangkan faktor biofisik sungai, faktor sosial ekonomi, kelembagaan dan hukum untuk dikembangkan sebagai kajian yang integratif. Salah satu bentuk pengelolaan DAS yang melibatkan peran serta masyarakat sekitar adalah upaya konservasi yaitu melalui pengelolaan lahan dengan peningkatan penutupan lahan yang menerapkan teknik agroforestry, holtikultura buah-buahan dan ekowisata.

Mengingat masih sedikitnya lokasi wisata di Kota Depok dan kebutuhan masyarakat setempat akan rekreasi, maka dapat dilakukan pengembangan kawasan wisata dengan pemanfaatan potensi sumberdaya alam lokal. Pengembangan tersebut diarahkan kepada upaya konservasi terhadap DAS Ciliwung sebagai bentuk pengelolaan terpadu kawasan DAS.

Melalui partisipasi masyarakat maka keseimbangan ekologi di sekitar sungai tetap terpelihara dan meringankan beban anggaran Pemerintah Kota Depok dalam pengelolaan DAS. Mengingat bahwa kelestarian DAS ditentukan oleh pola perilaku, keadaan sosial ekonomi dan tingkat pengelolaan yang sangat erat kaitannya dengan pengaturan kelembagaan (institutional arrangement), maka dibutuhkan perencanaan terkait Strategi Pengembangan Ekowisata dalam Pengembangan Partisipasi Masyarakat di Kota Depok.

\section{Perumusan Masalah}

Pengelolaan Sungai Ciliwung harus dilakukan secara terintegrasi dan tidak lepas dari peran kelembagaan Pemerintah dan stakeholder yang mendukungnya. Pemanfaatan bantaran Sungai Ciliwung sebagai objek pengembangan ekowisata membutuhkan peran serta masyarakat agar dapat berkelanjutan. Pelibatan peran serta masyarakat dalam perencanaan pembangunan sangat penting, guna menumbuhkan rasa tanggung jawab masyarakat terhadap objek wisata yang ada di daerahnya sehingga perlu diketahui bagaimana tingkat partisipasi masyarakat di Kawasan Depok Lama terhadap pengembangan ekowisata di sempadan Sungai Ciliwung.

Ekowisata memberikan peluang untuk mendapatkan keuntungan bagi penyelenggara, pemerintah dan masyarakat setempat, melalui kegiatan-kegiatan yang non ekstraktif, sehingga meningkatkan perekonomian daerah setempat dan dapat menjamin kesinambungan usaha. Untuk itu dibutuhkan informasi tentang jenis usaha produktif yang dapat berkembang sebagai 
multiplier effect dari pengembangan

ekowisata.

Sesuai kewenangannya, Pemerintah

Pusat bertanggungjawab terhadap perencanaan dan pengembangan wilayah yang bersifat makro, kewenangan pemerintah provinsi berskala meso, dan kewenangan Pemerintah Kota atau Kabupaten yang berskala mikro.

Pengelolaan DAS dilaksanakan berdasarkan prinsip partisipatif dan konsultatif pada setiap tingkatan pengelolaan untuk mendorong tumbuhnya komitmen bersama antar pihak yang berkepentingan, serta sasaran wilayah pengelolaan DAS adalah wilayah DAS yang secara utuh sebagai satu kesatuan ekosistem. Sehubungan dengan hal tersebut, informasi tentang proses-proses kebijakan yang ada terkait dengan pengembangan ekowisata di Kota Depok juga dibutuhkan.

\section{Tujuan Penelitian}

Tujuan umum dilaksanakannya kajian ini adalah untuk merumuskan strategi kebijakan dalam upaya konservasi melalui pengembangan kawasan ekowisata di DAS Ciliwung Kota Depok. Sedangkan, tujuan khusus yang ingin dicapai dalam kajian ini adalah:

1. Mengidentifikasi partisipasi masyarakat lokal yang mendukung upaya pengembangan ekowisata dan prasarana kota.

2. Mengidentifikasi aktivitas sosial dan ekonomi yang dapat dikembangkan melalui kegiatan ekowisata di Kota Depok.

3. Menganalisis proses kebijakan yang sudah ada terkait dengan pengembangan ekowisata di Kota Depok.

\section{TINJAUAN PUSTAKA}

\section{Perencanaan Tata Ruang Daerah Aliran Sungai (DAS)}

Dalam Undang-undang Nomor 26 Tahun 2007 tentang Penataan Ruang disebutkan bahwa Perencanaan Tata Ruang adalah suatu proses untuk menentukan struktur ruang dan pola ruang yang meliputi penyusunan dan penetapan rencana tata ruang. Perencanaan Tata Ruang ini berjenjang dari Perencanaan Tata Ruang Wilayah Nasional, Perencanaan Tata Ruang Wilayah Provinsi, Perencanaan Tata Ruang Wilayah Kabupaten dan Perencanaan Tata Ruang Wilayah Kota. Sedangkan pemanfaatan ruang adalah upaya untuk mewujudkan struktur ruang dan pola ruang sesuai dengan rencana tata ruang melalui penyusunan dan pelaksanaan program beserta pembiayaannya. Wilayah perencanaan atau pengelolaan tidak selalu berwujud wilayah administratif tapi berupa wilayah yang dibatasi berdasarkan kenyataan sifat-sifat tertentu pada wilayah baik sifat alamiah maupun non alamiah yang sedemikian rupa sehingga perlu direncanakan dalam kesatuan wilayah perencanaan/pengelolaan.

Berdasarkan Rencana Tata Ruang dan Wilayah (RTRW) Kota Depok, ruang terbuka hijau dialokasikan sebagai bagian dari kehidupan perkotaan di Kota Depok. Ruang terbuka hijau Kota Depok terdiri dari kawasan lindung/alami, hijau buatan dan hijau fungsional. Ruang terbuka hijau memiliki fungsi untuk perlindungan ekosistem, pengamanan lingkungan dari pencemaran, penciptaan iklim mikro, perlindungan tata air, meningkatkan citra estetika lingkungan, menciptakan kebersihan dan kesehatan, sarana rekreasi, dan sarana produksi. Alokasi ruang terbuka hijau di Depok dibedakan atas sempadan sungai, sempadan pipa gas, cagar alam, hutan kota, taman kota dan lingkungan, pemakaman, jalur hijau, pertanian, rekreasi dan wisata. 
Undang-Undang No. 7 tahun 2004 tentang Sumber Daya Air mendefinisikan Daerah Aliran Sungai (DAS) sebagai suatu wilayah daratan yang merupakan satu kesatuan dengan sungai dan anak-anak sungainya yang berfungsi menampung, menyimpan, dan mengalirkan air yang berasal dari curah hujan ke danau atau ke laut secara alami, yang batas darat merupakan pemisah topografis dan batas laut sampai dengan perairan yang masih terpengaruh aktivitas daratan.

Daerah Aliran Sungai secara umum didefinisikan sebagai suatu hamparan wilayah atau kawasan yang dibatasi oleh pembatas topografi (punggung bukit) yang menerima, mengumpulkan air hujan, sedimen, dan unsur hara serta mengalirkannya melalui anak-anak sungai dan keluar pada satu titik (outlet). Oleh karena itu, pengelolaan DAS menempatkan DAS sebagai suatu unit pengelolaan yang pada dasarnya merupakan usaha-usaha penggunaan sumberdaya alam secara rasional untuk mencapai tujuan produksi pertanian yang optimum, secara lestari disertai upaya menekan kerusakan seminimum mungkin. Dua indikator tata air yang utama pada pengelolaan DAS adalah kuantitas dan kualitas air (Agus dan Widianto, 2004).

Dari definisi diatas, maka dapat dikemukakan bahwa DAS merupakan ekosistem, dimana unsur organisme dan lingkungan biofisik serta unsur kimia berinteraksi secara dinamis dan di dalamnya terdapat keseimbangan inflow dan outflow dari material dan energi. Ekosistem DAS, terutama DAS bagian hulu merupakan bagian yang penting karena mempunyai fungsi perlindungan terhadap keseluruhan bagian DAS. Perlindungan ini antara lain dari segi fungsi tata air, oleh karenanya perencanaan DAS hulu seringkali menjadi fokus perhatian mengingat dalam suatu DAS, bagian hulu dan hilir mempunyai keterkaitan biofisik melalui daur hidrologi.

Aktivitas perubahan tata guna lahan dan atau pembuatan bangunan konservasi yang dilaksanakan di daerah hulu dapat memberikan dampak di daerah hilir dalam bentuk perubahan fluktuasi debit air dan transport sedimen serta material terlarut lainnya atau non-point pollution. Adanya bentuk keterkaitan daerah hulu-hilir seperti tersebut diatas maka kondisi suatu DAS dapat digunakan sebagai satuan unit perencanaan sumberdaya alam termasuk pengelolaan berkelanjutan.

Pada pengelolaan DAS indikator paling memungkinkan adalah melihat kondisi tata airnya, menurut Agus dan Widianto (2004), beberapa indikator tata air yang utama adalah:

1) Indikator kuantitas air. Kondisi kuantitas air ini sangat berkaitan dengan kondisi tutupan vegetasi lahan di DAS yang bersangkutan. Bila tutupan vegetasi lahan DAS yang bersangkutan berkurang dapat dipastikan perubahan kuantitas air akan terjadi. Sehingga setiap pelaksanaan kegiatan yang bermaksud mengurangi tutupan lahan pada suatu tempat maka harus diiringi dengan usaha konservasi. Indikator ini dapat dilihat dari besarnya air limpasan permukaan maupun debit air sungai.

2) Indikator kualitas air. Kondisi kualitas air disamping dipengaruhi oleh tutupan vegetasi lahan seperti pada kondisi kuantitas, tetapi juga dipengaruhi oleh buangan domestik, buangan industri, pengolahan lahan, pola tanam, dll. Dengan demikian bila system pengelolaan limbah, pengolahan lahan, dan pola tanam dapat dengan mudah diketahui kejanggalannya dengan melihat indikator kualitas air.

Dengan demikian, mengetahui indikator tata air yang dapat mudah dilihat dengan pengamatan masyarakat umum yang diharapkan kontrol pelaksanaan pembangunannya dapat dilakukan dengan lebih terbuka. Sebagai gambaran bahwa suatu daerah aliran sungai dapat dikatakan masih baik apabila: 
1) Memberikan produksi tinggi bagi keperluan kehidupan dalam DAS yang bersangkutan.

2) Menjamin kelestarian DAS, dimana erosi yang terjadi di bawah erosi yang dapat ditoleransi.

3) Terdapat kelenturan, dimana bila terjadi gangguan pada salah satu bagian, maka bagian lain mampu memberikan supply/bantuan.

4) Bersifat pemerataan, dimana setiap stakeholder yang ada di dalam DAS mampu berperan sesuai dengan kemampuan yang dipunyai dan mendapatkan imbalan yang sesuai. (Agus dan Widianto, 2004).

\section{Pengembangan Ekowisata}

Menurut Holloway dan Plant dalam Yuliandra (2007), wisata merupakan suatu bentuk pemanfaatan sumberdaya alam yang mengandalkan jasa alam untuk kepuasan manusia. Mulyadi dan Nurhayati (2002) juga menyatakan bahwa pariwisata adalah serangkaian kegiatan yang dilakukan wisatawan baik individu maupun berkelompok dengan menikmati jasa dan industri pariwisata, transportasi, akomodasi, restoran, hiburan, dan sebagainya. Kemudian menurut Suwantoro (1997), dalam kepariwisataan, masyarakat dapat diidentifikasikan kedalam empat komponen pokok yang memiliki fungsi yang terjalin erat satu sama lain, yaitu komponen pemerintah, penyelenggara pariwisata, masyarakat penerima pariwisata, dan wisatawan.

\section{1) Komponen Pemerintah}

Komponen pemerintah bercirikan mampu meningkatkan sumber dana terutama sumber devisa sebanyakbanyaknya serta menciptakan lapangan kerja dan berusaha seluas-luasnya bagi seluruh warganya.

2) Komponen Penyelenggara Pariwisata

Komponen penyelenggara pariwisata terselenggara dengan lancar dan memberikan keuntungan sebesar-besarnya.

3) Komponen Masyarakat Penerima Pariwisata

Komponen masyarakat penerima pariwisata sebagai pemilik wilayah dan pendukung serta pelaku budaya setempat cenderung bertujuan mengupayakan kelestarian wilayah dan kehidupan di alam budayanya agar tidak terancam dan tidak tercemar.

4) Komponen Wisatawan

Komponen wisatawan, baik nusantara maupun mancanegara, cenderung berkeinginan untuk mendapatkan kepuasan dan kenyamanan selama berwisata.

Pariwisata di Indonesia telah dianggap sebagai salah satu sektor ekonomi penting, bahkan di beberapa wilayah sektor ini dapat menjadi penghasil devisa. Disamping menjadi mesin penggerak ekonomi, pariwisata juga merupakan wahana yang menarik diantaranya dampak industri pariwisata menyusup ke berbagai kegiatan perekonomian dan menyebar secara pesat melalui beragam industri terkait. Dampak ekonomi itu mencakup spectrum kebijakan yang luas, menyangkut kesempatan berusaha, kesempatan kerja, transportasi, akomodasi, prasarana, pengembangan wilayah, perpajakan, perdagangan dan lingkungan.

Pembangunan pariwisata memerlukan dukungan kebijakan pariwisata yang tepat, yang mampu menjadi pijakan dan panduan bagi tindakan strategik di masa mendatang. Hal ini penting bagi pembangunan pariwisata yang berkelanjutan. Ditinjau dari kacamata ekonomi makro, pengembangan pariwisata memberikan dampak positif (Yoeti, 2008).

Dampak positif tersebut sejalan dengan tujuan pengembangan pariwisata sesuai dengan Undang-Undang No. 9 Tahun 1990 tentang Kepariwisataan. Selain dampak positif, pariwisata juga memiliki dampak negatif, terutama dampak terhadap kelestarian lingkungan 
dan warisan budaya nasional. Hal ini memerlukan campur tangan pemerintah dalam hal pengendalian eksplorasi lingkungan, untuk mencegah kerusakan sumber-sumber hayati yang dapat menghilangkan daya tarik suatu daerah dalam jangka panjang, pembuangan sampah sembarangan, serta pembuangan limbah kegiatan wisata yang merusak air sungai, danau dan laut.

Ekowisata menurut The International Ecotourism Society (TIES, 1990) didefinisikan sebagai suatu bentuk perjalanan wisata ke area alami yang dilakukan dengan tujuan mengkonservasi lingkungan dan melestarikan kehidupan dan kesejahteraan penduduk setempat. Menurut Fandeli dan Mukhlison (2000), ekowisata merupakan bentuk wisata yang dikelola dengan pendekatan konservasi dengan dua aspek yang perlu dipertimbangkan, yaitu aspek destinasi dan aspek market.

The Ecotourism Society dalam Eplerwood (1999) menyebutkan ada delapan prinsip ekowisata, yaitu mencegah dan menanggulangi dampak dari aktivitas wisatawan terhadap alam dan budaya, pendidikan konservasi lingkungan, pendapatan langsung untuk kawasan, partisipasi masyarakat dalam perencanaan, penghasilan masyarakat, menjaga keharmonisan dengan alam, daya dukung lingkungan, dan peluang penghasilan pada porsi yang besar terhadap negara. Cooper et al. (1996) menyatakan bahwa masalah dampak suatu kegiatan seperti pariwisata, baik pariwisata massal maupun ekotourisme terkait erat dengan konsep daya dukung. Menurut Ceballos-Lascurain (1996), daya dukung ekowisata tergolong spesifik dan lebih berhubungan dengan daya dukung lingkungan (biofisik dan sosial) terhadap kegiatan pariwisata dan pengembangannya.

\section{Partisipasi}

Istilah partisipasi mempunyai arti yang luas dan sering diasumsikan sebagai kontribusi finansial, material, dan tenaga dalam suatu program. Rifkin et al. (1990) memberi batasan partisipasi masyarakat sebagai keterlibatan masyarakat, kontribusi dari masyarakat dalam pelaksanaan kegiatan yang telah diputuskan, dan bersama-sama memanfaatkan hasil program sehingga masyarakat mendapatkan keuntungan dari program tersebut.

Dalam pengertian partisipasi tercakup dua sistem yang terlibat dalam suatu kegiatan. Kedua sistem itu adalah sistem dari pemerintah yang merupakan provider di pihak kesatu, dan dengan sistem dari masyarakat di pihak lain. Kedua pihak secara fungsional sering mempunyai karakteristik dan pandangan yang sangat berbeda dalam konteks partisipasi. Berdasarkan pandangan bahwa program pengembangan masyarakat adalah sama dengan pengembangan kelompok masyarakat perdesaan yang miskin (rural poor community). Pandangan ini sering ada pada sudut pandang pemerintah atau provider, partisipasi masyarakat seolaholah merupakan kewajiban yang harus diadakan oleh 'masyarakat yang mendapat bantuan'. Dalam keadaan tersebut, masyarakat tidak mempunyai otoritas terhadap kegiatan karena semuanya telah 'diatur' dan 'dijadwal' oleh pemberi kegiatan.

Di pihak lain,
menyatakan
pengembangan itu dapat pada siapa saja, tidak peduli apakah kelompok sasaran tersebut merupakan kelompok masyarakat perdesaan yang miskin ataupun kelompok masyarakat di kota yang sudah cukup dari segi sosial ekonomi. Pendapat itu menganggap bahwa partisipasi merupakan hak dari masyarakat. Masyarakat boleh menggunakan atau tidak menggunakan 'hak' tersebut dalam suatu kegiatan yang diadakan oleh pemberi kegiatan. Apabila 
pemberi kegiatan menginginkan partisipasi masyarakat, diperlukan suatu pendekatan tertentu untuk mendapatkannya (Arnstein, 1969).

Oakley dan Marsden (1984) menyimpulkan bahwa banyaknya variasi dalam pelaksanaan partisipasi masyarakat disebabkan oleh setiap batasan menonjolkan dimensi yang berbeda dari partisipasi masyarakat. Satu pendapat menyatakan bahwa jika ada keterlibatan dari masyarakat, bagaimanapun bentuk dan prosesnya, maka dikatakan bahwa masyarakat telah berpartisipasi dalam kegiatan tersebut. Hal itu memang tidak keliru tetapi masih kurang tepat karena hanya melihat aspek kuantitatif dari partisipasi. Implementasi pendapat itu sering berupa mobilisasi sumberdaya masyarakat dalam suatu kegiatan tanpa masyarakat tahu apa tujuan kegiatan tersebut dan keuntungan apa yang akan diperoleh dengan keterlibatannya.

Sedangkan peran serta masyarakat menurut Arnstein (1969) adalah bagaimana masyarakat dapat terlibat dalam perubahan sosial yang memungkinkan mereka mendapatkan bagian keuntungan dari kelompok yang berpengaruh. Partisipasi masyarakat tersebut bertingkat, sesuai dengan gradasi derajat wewenang dan tanggungjawab yang dapat dilihat dalam proses pengambilan keputusan. Gradasi tersebut kemudian digambarkan sebagai sebuah tangga dengan delapan tingkatan yang menunjukkan peningkatan partisipasi.

\section{Kebijakan Publik}

Menurut Friedrich seperti dikutip Winarno (2007), kebijakan merupakan arah tindakan yang diusulkan oleh seseorang, kelompok atau pemerintah dalam suatu lingkungan tertentu yang memberikan hambatan-hambatan dan peluang-peluang terhadap kebijakan yang diusulkan untuk menggunakan dan mengatasi dalam rangka mencapai suatu tujuan atau merealisasikan suatu tujuan atau merealisasikan suatu sasaran atau suatu maksud tertentu. Model pendekatan dalam kebijakan publik dapat dibagi menjadi pendekatan kelompok, proses fungsional, kelembagaan (institusional), dan peran serta warga negara.

\section{Kerangka Pemikiran}

Daerah Aliran Sungai di beberapa lokasi di Indonesia memiliki beban amat berat dikarenakan pertambahan laju kepadatan penduduknya yang tinggi dan pemanfaatan sumberdaya alamnya yang intensif sehingga terdapat indikasi kondisi DAS semakin menurun. Disisi lain tuntutan terhadap kemampuannya dalam menunjang sistem kehidupan, baik masyarakat di bagian hulu maupun hilir demikian besarnya. Kondisi perairan badan air Sungai Ciliwung di Kawasan Depok Lama relatif belum banyak terkena pencemaran serta DAS-nya cukup asri dan hijau untuk pengelolaan kawasan konservasi. Pengelolaan DAS dengan cara konservasi bertujuan untuk mempertahankan daya dukung lingkungan, peningkatan peran serta masyarakat dan kelembagaan, peningkatan aktivitas sosial dan ekonomi, dan peningkatan pendapatan masyarakat dimana partisipasi masyarakat dalam pelaksanaan pembangunan merupakan salah satu syarat mutlak.

Arnstein (1969) menformulasikan peran serta masyarakat sebagai bentuk dari kekuatan rakyat (citizen participation is citizen power). Dimana terjadi pembagian kekuatan (power) yang memungkinkan masyarakat yang tidak berpunya (the havenot citizens) yang sekarang dikucilkan dari proses politik dan ekonomi untuk terlibat kelak. Metode Arnstein yang dikenal sebagai delapan tingkat partisipasi digunakan untuk menilai tingkat partisipasi masyarakat di lokasi penelitian. Melalui pengembangan ekowisata ini diharapkan terjadi peningkatan peran serta masyarakat dan peningkatan aktivitas sosial ekonomi. Masyarakat yang bersedia berperan serta akan membantu dalam upaya konservasi sehingga dapat mengurangi beban 
anggaran pemerintah untuk pengelolaan dapat dilihat pada Gambar 1. lingkungan. Kerangka penelitian kajian ini

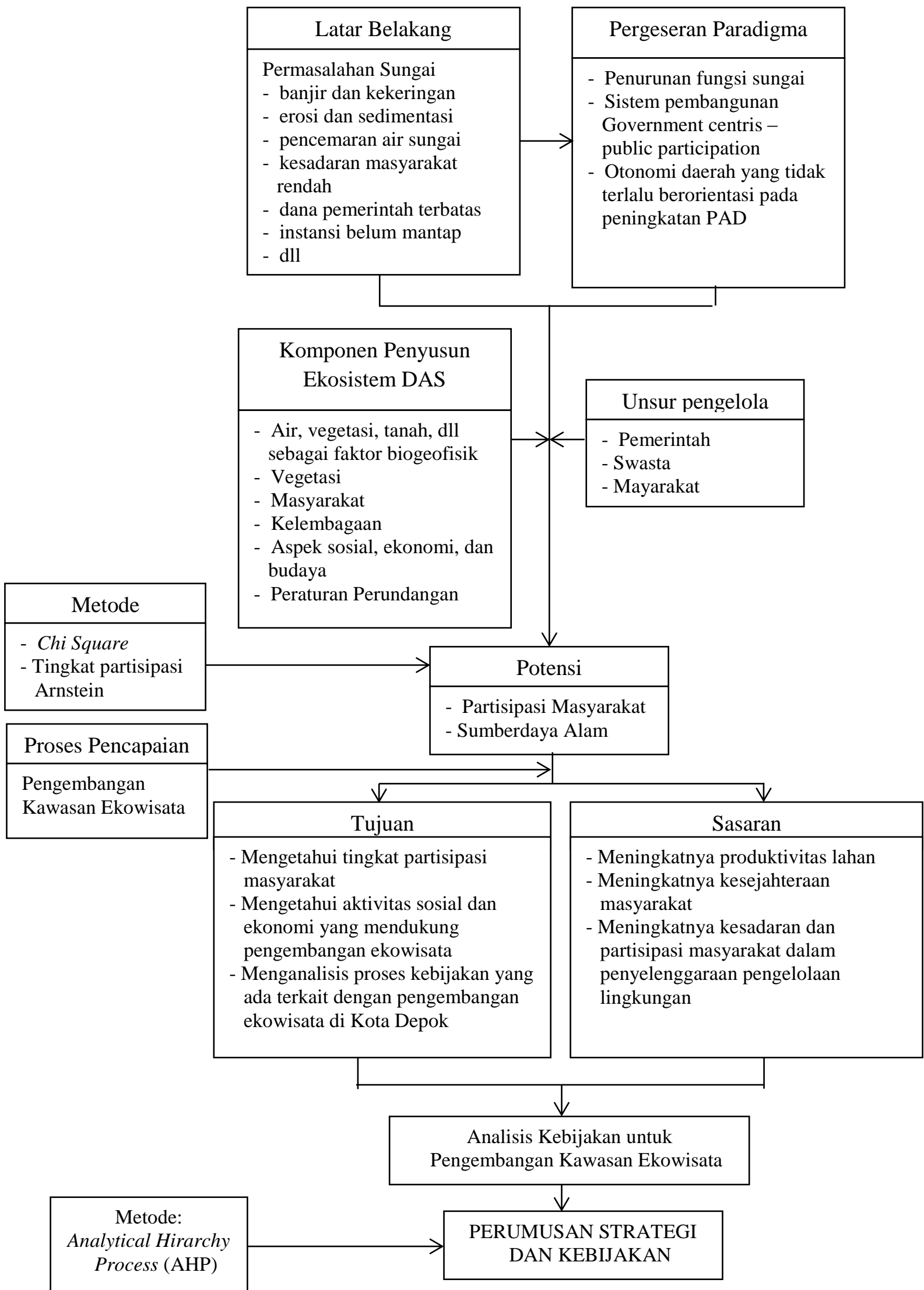

Gambar 1. Kerangka Pendekatan Studi 


\section{METODE PENELITIAN}

\section{Lokasi dan Waktu Penelitian}

Lokasi penelitian dilaksanakan di zona koridor Sungai Ciliwung kawasan Kota Depok Lama Kecamatan Sukmajaya yang peruntukannya akan dikembangkan sebagai kawasan wisata. Penentuan daerah ini atas dasar pertimbangan karena di wilayah ini mencakup area rekomendasi pengembangan ruang terbuka dan tata hijau berdasarkan Rencana Detail Tata Ruang Bagian Wilayah Kota (BWK) VIII Sukmajaya pada rencana pemanfaatan Tahun 2013. Penelitian dilakukan selama dua bulan mulai dari Bulan November hingga bulan Desember 2008.

\section{Jenis dan Sumber Data}

Dalam penelitian ini ada dua jenis data yang dikumpulkan, yaitu data primer dan data sekunder. Data Primer dikumpulkan dari seluruh stakeholder yang menjadi sasaran evaluasi secara langsung. Proses untuk mendapatkan data primer ini melalui survei lapangan untuk menilai potensi fisik, teknik wawancara terhadap responden dan metode kuesioner untuk dapat menyerap aspirasi. Data sekunder yang diperoleh berupa dokumen atau referensi yang berkaitan dengan pengelolaan kawasan sempadan sungai, perubahan tata guna lahan, data demografis dan sosial ekonomi masyarakat yang didapat dari instansi pemerintah setempat.

\section{Metode Analisis}

Analisis kajian ini terdiri dari tiga analisis utama, yaitu:

1. Analisis penilaian partisipatif dengan analisis deskriptif terhadap data primer (kuesioner) yang diperoleh melalui responden, pengamatan lapangan dan wawancara maupun data sekunder yang diperoleh dari instansi terkait. Distribusi variabel penelitian dianalisis menggunakan statistik deskriptif, dengan tingkat partisipasi dianalisis berdasarkan kerangka teori yang dikemukakan Arnstein.

2. Analisis identifikasi usaha produksif dengan analisis statistik deskriptif terhadap distribusi variabel, kemudian hubungan untuk data yang menggunakan skala nominal dianalisis dengan uji korelasi Chi-Square.

3. Metode Analitical Hirarchy Process (AHP) digunakan untuk perumusan kebijakan karena kemampuannya dalam memecahkan masalah yang multi objektif dan multi kriteria serta fleksibilitasnya yang tinggi terutama dalam pembuatan hirarki (Falatehan, 2007).

\section{HASIL DAN PEMBAHASAN}

\section{Partisipasi Masyarakat}

\section{Terdapat enam kelompok responden berdasarkan klasifikasi pendidikan dan pekerjaan, yaitu kelompok} A (SD-SLTP, PNS), kelompok B (SDSLTP, Non PNS), kelompok C (SLTA, PNS), kelompok D (SLTA, Non PNS), kelompok E (Perguruan Tinggi, PNS), dan kelompok F (Perguruan Tinggi, Non PNS) dimana kelompok $\mathrm{D}$ mendominasi dengan persentase 47 persen, diikuti kelompok B (23\%) kelompok E (13\%).

Berdasarkan hasil pengamatan (Gambar 2), pengembangan sarana rekreasi dan wisata merupakan pilihan yang banyak diminati oleh setiap kelompok responden disamping pilihan yang lainnya. Hal ini menunjukkan bahwa masyarakat setempat memiliki ketertarikan dalam menerima perubahan lingkungan untuk penyegaran rohani atau wisata sekaligus memiliki wahana yang bersifat edukatif. Berdasarkan data kuesioner yang diperoleh di lapangan, masyarakat banyak melakukan kegiatan pemancingan dan penanaman pohon $(36 \%)$. Pada tingkat pendidikan yang tinggi terlihat lebih dari 50 persen dari jumlah kelompok responden melakukan pengolahan sampah dengan 
mekanisme tertentu. Sedangkan responden dengan tingkat pendidikan lebih rendah melakukan pengelolaan lingkungan dengan cara lebih konvensional yang dilakukan secara kerja bakti maupun swadaya.

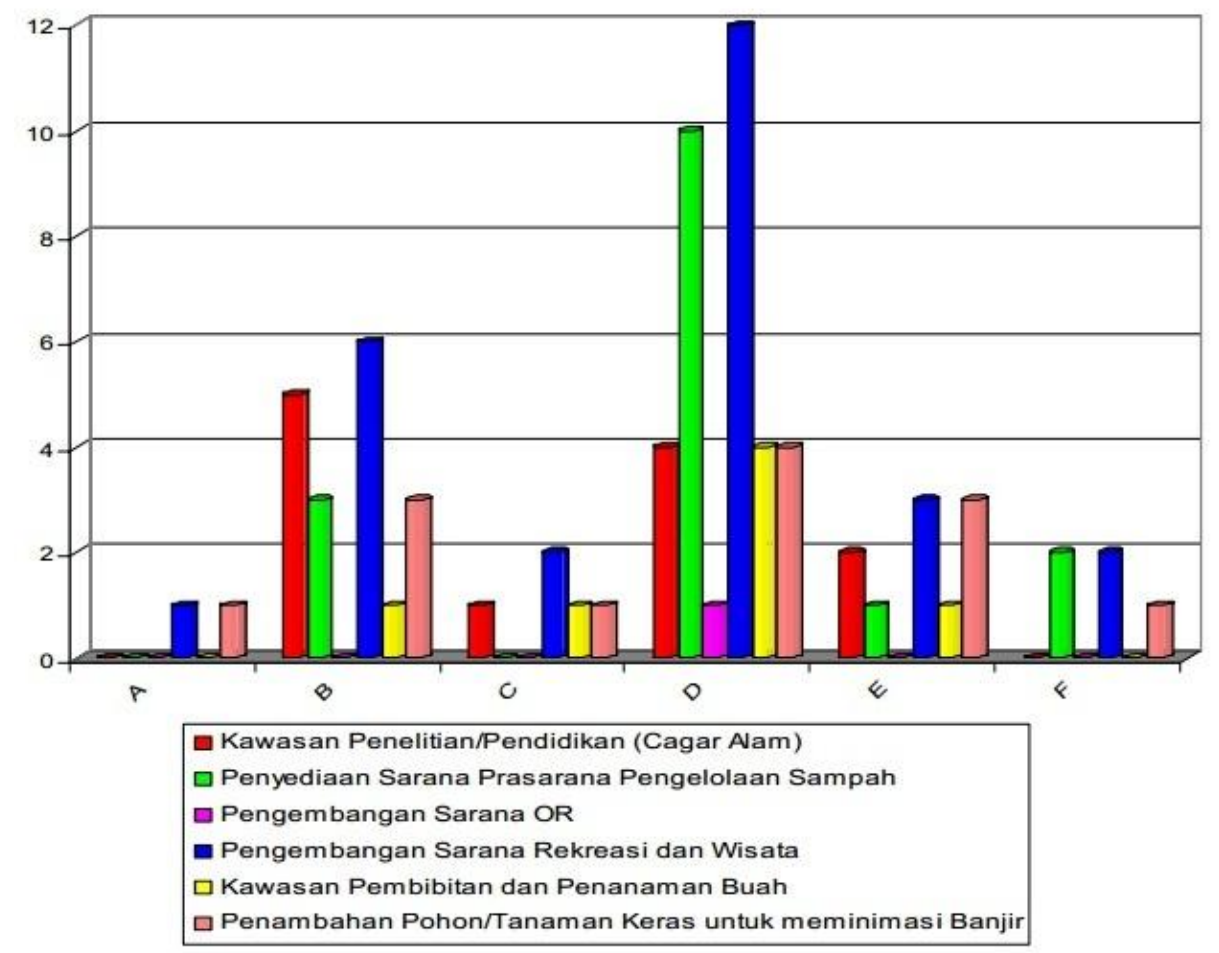

Gambar 2. Sebaran Aspirasi Masyarakat Terhadap Pengembangan Kawasan

Untuk penilaian partisipasi, unsur masyarakat yang dinilai yaitu tokoh masyarakat, LPM, RW, RT, karang taruna, kelurahan, kecamatan, dan pemerintah daerah. Peranan unsur masyarakat dalam pengelolaan lingkungan menurut responden yaitu masih rendah (kelompok A, C), sedang (kelompok B, D, E, F). Untuk aspek partisipasi dalam kelembagaan, responden menilai efektifitas pertemuan pertemuan rutin di Kelurahan Kalimulya yang membahas pelaksanaan program kegiatan yang berkaitan dengan pengelolaan lingkungan, K3, keamanan dan ketertiban di tingkat kelurahan adalah cukup efektif. Untuk partisipasi dalam pembangunan, 90 persen responden setuju melakukan penggalangan dana secara swadaya demi realisasi rencana pengembangan ekowisata, salah satunya melalui pembangunan jalan lingkungan dan pembangunan fasilitas umum. Terkait dengan partisipasi dalam pengembangan ekowisata, sebagian besar responden mendukung Pemda sejak perencanaan pengembangan (33\%).

Berdasarkan tingkat pastisipasi masyarakat menurut Arnstein melalui typologinya yang dikenal dengan Delapan Tangga Peran Serta Masyarakat (Eight Rungs on the Ladder of Citizen Participation) yang terdiri dari tiga bagian utama yaitu non participation, degrees of tokenism, dan citizen power, menunjukkan bahwa tingkat partisipasi masyarakat di lokasi sempadan Sungai Ciliwung Kelurahan Kalimulya dalam perencanaan pembangunan berada pada tangga pertama Non Participation dan tangga kedua Tokenism (Gambar 3). 


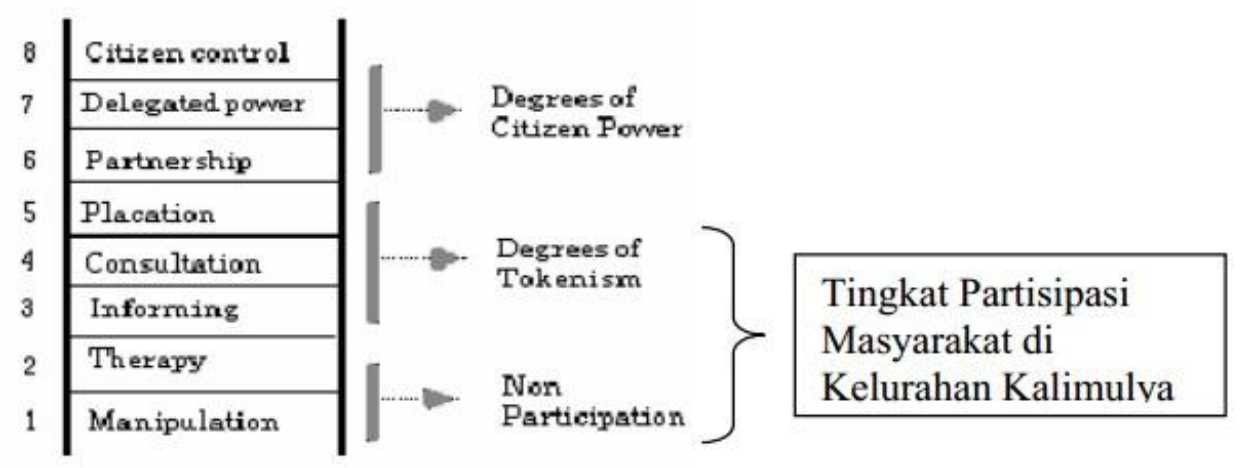

Gambar 3. Gambaran Tingkat Partisipasi Masyarakat Kelurahan Kalimulya

Dengan pengertian bahwa tangga terendah atau Non Partisipasi adalah bentuk-bentuk peran serta yang dinamakan terapi dan manipulasi. Sedangkan di tangga kedua atau tingkat Tokenisme yaitu tingkat dimana peran serta masyarakat didengar dan berpendapat, tetapi mereka tidak memiliki kemampuan untuk mendapatkan jaminan bahwa pandangan mereka akan dipertimbangkan oleh pemegang keputusan. Peran serta pada tingkat ini memiliki kemungkinan yang sangat kecil untuk menghasilkan perubahan pada masyarakat. Termasuk dalam tingkat "Tokenisme" adalah (3) penyampaian informasi (informing); (4) konsultasi; dan (5) peredaman kemarahan (placation).

Pemahaman diatas dapat dijelaskan bahwa masyarakat di lokasi setempat beserta unsur masyarakat telah menghadiri, mendengar dan mengusulkan program pembangunan tetapi mereka tidak memiliki jaminan bahwa apa yang diusulkan dapat diterima oleh pengambil keputusan. Sebagai contoh masyarakat sudah melakukan beberapa kegiatan pengelolaan lingkungan, namun program pelatihan yang didapat dari pemerintah ataupun fasilitasnya masih kurang memadai.

Kondisi di Kelurahan Kalimulya yang dianggap menjadi penghambat dalam implementasi program pengembangan kawasan ekowisata antara lain disebabkan oleh kesadaran masyarakat yang rendah (25\%), peran Pemda yang masih lemah $(13 \%)$, kurangnya sosialisai $(12 \%)$, serta kurangnya pengetahuan teknologi (11\%) dengan dominasi dari kelompok D (32\%).

Berdasarkan potensi pertanian dan perikanan yang ada, masyarakat setempat berkeinginan agar Pemerintah dapat memfasilitasi pengembangan usahanya dan membuka lapangan pekerjaan baru. Berdasarkan hasil penelitian, kecenderungan responden yaitu pada pilihan pengembangan wisata, pengembangan tanaman buah-buahan dan kegiatan memancing atau perikanan dimana penyebaran minat terhadap potensi kegiatan ekonomi tersebut cukup dipengaruhi oleh tingkat pendidikan.

Masyarakat dengan pendidikan yang lebih tinggi mengharapkan adanya pengembangan kegiatan yang lebih membutuhkan kemampuan teknis dan edukatif khususnya kelompok responden tingkat Perguruan Tinggi, sedangkan bagi masyarakat yang berpendidikan rendah (SD-SLTA) lebih memilih pada kegiatan perdagangan saja. Kegiatan pengembangan transportasi dan agrobisnis merupakan opsi yang diberikan bagi para responden namun tidak memperoleh angka yang signifikan (Tabel 1). 
Tabel 1. Frekuensi dan Persentase Potensi Pengembangan Usaha Produktif Menurut Responden Berdasarkan Tingkat Pendidikan

\begin{tabular}{|c|c|c|c|c|c|c|c|c|c|c|}
\hline \multirow[b]{2}{*}{ No } & \multirow[b]{2}{*}{$\begin{array}{c}\text { Tingkat } \\
\text { Pendidikan }\end{array}$} & \multicolumn{8}{|c|}{ Jenis Potensi Usaha Produktif } & \multirow[b]{2}{*}{ Total } \\
\hline & & $\begin{array}{c}\text { Perdagangan } \\
\text { tanaman } \\
\text { hias }\end{array}$ & $\begin{array}{c}\text { Perdagangan } \\
\text { makanan } \\
\text { /minuman }\end{array}$ & $\begin{array}{c}\text { Hasil } \\
\text { Kreasi } \\
\text { dan } \\
\text { Daur } \\
\text { Ulang }\end{array}$ & Transportasi & Agribisnis & Wisata & $\begin{array}{c}\text { Tanaman } \\
\text { Buah }\end{array}$ & Perikanan & \\
\hline \multirow[t]{2}{*}{1} & SD-SLTP & 1 & 3 & 1 & & & & & 3 & 8 \\
\hline & Persentase & 12,5 & 37,5 & 12,5 & & & & & 37,5 & 100 \\
\hline \multirow[t]{2}{*}{2} & SLTA & 2 & 2 & & & & 5 & 4 & 3 & 16 \\
\hline & Persentase & 12,5 & 12,5 & & & & 31,3 & 25 & 18,8 & 100 \\
\hline \multirow[t]{4}{*}{3} & Perguruan Tinggi & & 1 & 1 & & & 3 & 1 & & 6 \\
\hline & Persentase & & 16,7 & 16,7 & & & 50 & 16,7 & & 100 \\
\hline & TOTAL & 3 & 6 & 2 & & & 8 & 5 & 6 & 30 \\
\hline & Persentase & 10 & 20 & 6,7 & & & 26,7 & 16,7 & 20 & 100 \\
\hline
\end{tabular}

\section{Kebijakan Pengembangan Ekowisata}

Program Pemerintah Kota Depok untuk meningkatkan potensi wisata saat ini adalah penguatan kawasan wisata, perluasan akses dan pembangunan sarana, peningkatan promosi dan pameran, peningkatan dan penyediaan SDM terampil melalui pelatihan, dan peningkatan peran pelaku usaha masyarakat melalui pendirian koperasi dan pembentukan wadah bersama. Hasil yang dicapai bahwa selama ini pemerintah kurang melakukan sosialisasi kepada publik seputar pariwisata, akibatnya potensi pariwisata di Depok belum dikenal dengan baik. Selain itu, promosi dilakukan secara sepihak yakni oleh pemerintah Kota Depok sendiri, sedangkan para pelaku pariwisata tidak terlalu dilibatkan. Kemudian program pariwisata juga disusun dan dilaksanakan sendiri oleh pemerintah daerah sehingga hasilnya banyak yang tidak tepat sasaran.

Program pemerintah Kota Depok dalam pengembangan pariwisata yang secara langsung melibatkan partisipasi masyarakat di lokasi studi hanya dapat diwujudkan dalam bentuk pelatihan. Salah satu upaya Pemerintah Kota Depok untuk menjembatani aspirasi masyarakat dengan penyusunan program pariwisata ke depan, yaitu dengan membangun Tourist Information Centre (TIC) atau Pusat Informasi Pariwisata. Namun pada batas tertentu potensi-potensi wisata di Kota Depok sudah dimulai dikembangkan dan bermunculan. Pemerintah Kota Depok telah menyusun kajian yang mendorong berkembangnya sektor pariwisata yaitu Rencana Induk Pengembangan Pariwisata Daerah Kota Depok (RIPDA) yang memuat rencana kebijakan pemerintah untuk pariwisata.

Berdasarkan hasil survei di lapangan terdapat beberapa kendala yang dihadapi pemerintah Kota Depok dalam pengembangan sektor pariwisata, antara lain aksesibilitas, keterbatasan informasi dan promosi, potensi obyek wisata di Kota Depok, keterbatasan SDM trampil, keterbatasan atraksi, keterbatasan sarana hotel dan restoran di beberapa obyek wisata, belum ada komunikasi dan jaringan antara obyek wisata, dukungan kebijakan dari pemda terhadap pengembangan obyek wisata di Kota Depok belum maksimal, serta kemacetan.

Dengan adanya pengembangan ekowisata di Kota Depok, responden mengharapkan dapat memperoleh manfaat ekonomi (economical benefit) dari adanya aktivitas ekonomi yang dikembangkan. Kehadiran wisatawan, khususnya ekowisatawan ke tempat-tempat yang masih alami memberikan peluang bagi penduduk setempat untuk mendapatkan penghasilan alternatif dengan menjadi pemandu wisata, porter, membuka homestay, pondok ekowisata (ecolodge), warung dan usaha-usaha lain yang berkaitan dengan ekowisata, sehingga dapat meningkatkan kesejahteraan mereka atau meningkatkan kualitas hidup penduduk lokal, baik secara materiil, spirituil, kulturil maupun intelektual. Hasil 
pemantauan menunjukkan bahwa sebanyak 31 persen harapan masyarakat terkait dengan adanya peningkatan peluang kerja dan sebanyak 24 persen terkait peningkatan kegiatan ekonomi lokal dan wilayah.

\section{Analisis Hasil Studi AHP}

Berdasarkan hasil analisis, faktorfaktor yang berperan dalam pengembangan ekowisata di Kota Depok antara lain daya dukung ekowisata, konservasi, peran serta dan pemberdayaan masyarakat, dan pengembangan usaha produktif. Kemudian alternatif kebijakan untuk pengembangan ekowisata meliputi penataan kawasan, pembiayaan, pengembangan kapasitas unsur masyarakat, serta pengadaan sarana dan prasarana wisata.

Analisis pendapat gabungan para responden menunjukkan bahwa aspek peran serta dan pemberdayaan masyarakat (nilai bobot 0,344) merupakan aspek paling penting yang perlu diperhatikan dalam pengembangan ekowisata di Kota Depok. Aspek berikutnya yang perlu diperhatikan adalah aspek daya dukung ekowisata (nilai bobot 0,229), aspek konservasi (nilai bobot 0,226), dan aspek pengembangan usaha produktif (nilai bobot 0,202 ). Hirarki pemilihan kebijakan untuk pengembangan ekowisata beserta nilai bobot untuk masing-masing faktor dapat dilihat pada Gambar 4.

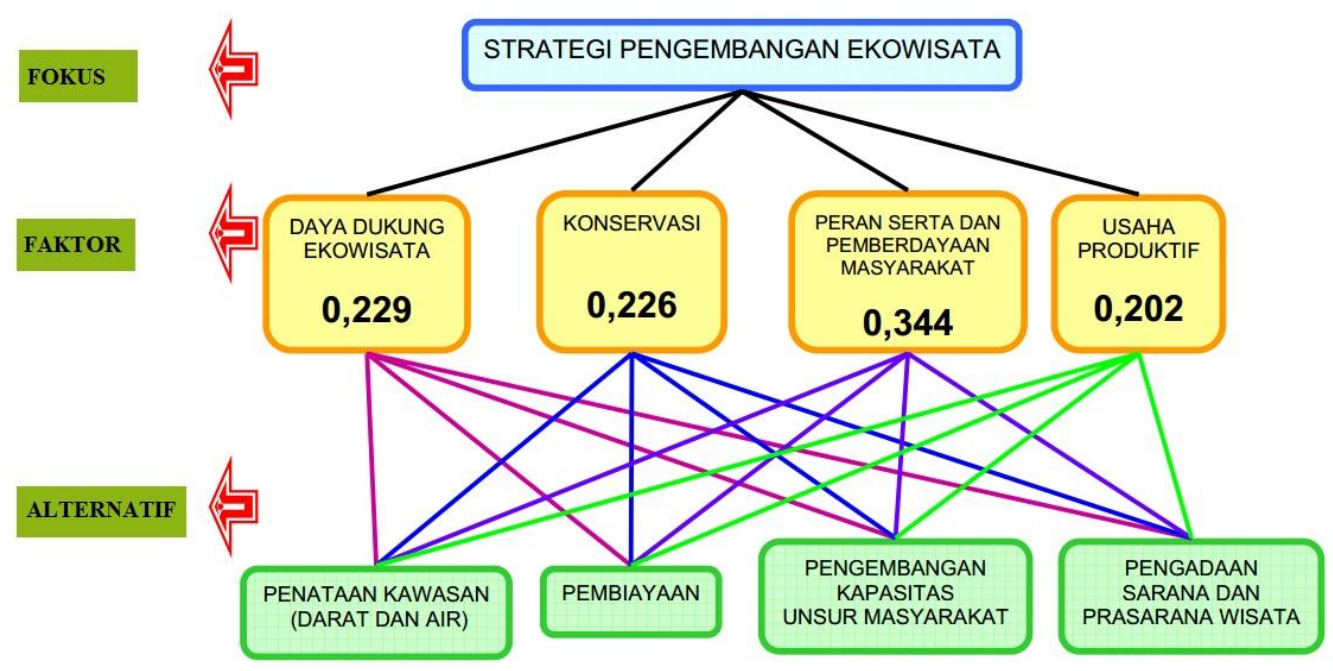

Gambar 4. Hirarki Pemilihan Kebijakan Pengembangan Ekowisata Beserta Bobot Faktornya

Terpilihnya aspek peran serta dan pemberdayaan masyarakat sebagai prioritas utama yang harus diperhatikan dalam pengembangan ekowisata di Kota Depok mencerminkan bahwa peranan masyarakat erat kaitannya dengan pemantapan, pembudayaan, pengalaman dan pelaksanaan demokrasi. Selanjutnya, Kemampuan daya dukung lingkungan ekowisata harus tetap dipertahankan karena jika daya tampung obyek wisata alam tersebut dilampaui, maka akan terjadi kemerosotan sumberdaya, kepuasan pengunjung tidak terpenuhi, dan akan memberikan dampak merugikan terhadap masyarakat, ekonomi dan budaya. Lalu untuk aspek konservasi, dengan dilakukannya konservasi sumberdaya alam hayati di kawasan ekowisata diharapkan akan terwujud kelestarian sumberdaya alam hayati serta keseimbangan ekosistemnya sehingga dapat mendukung upaya peningkatan kesejahteraan masyarakat dan mutu kehidupan manusia yang terkait dengan kegiatan ekowisata tersebut. Usaha produktif juga perlu dilakukan untuk memberikan dampak yang cukup signifikan terhadap perkembangan kegiatan ekowisata. 
Faktor daya dukung menjadi dasar dalam pengembangan suatu kawasan. Hasil analisis menunjukkan kriteria yang dipandang utama oleh para responden adalah sumberdaya manusia sebagaimana pada pengembangan kapasitas unsur masyarakat (nilai bobot 0,309). Selanjutnya, faktor konservasi juga menekankan pengembangan kapasitas unsur masyarakat sebagai faktor signifikan (nilai bobot 0,298). Pengembangan kapasitas unsur masyarakat ditinjau dari faktor peran serta menghasilkan bobot paling tinggi dan menunjukkan perbedaan yang signifikan terhadap alternatif lainnya (nilai bobot 0,400). Untuk faktor pengembangan usaha produktif, diperoleh dua alternatif utama, yaitu pengembangan kapasitas unsur masyarakat (nilai bobot 0,339 ) dan pembiayaan (nilai bobot 0,314 ).

\section{Rumusan Strategi dan Program}

Rumusan strategi pengembangan ekowisata disusun dengan beberapa pertimbangan sesuai dengan kondisi yang berlaku di Kota Depok. Melalui analisis dengan metode AHP, nilai bobot tertinggi diperoleh pengembangan kapasitas unsur masyarakat, maka prioritas rancangan program yang disusun meliputi:

1. Aspek Pengembangan Sumberdaya Manusia, antara lain penyusunan kurikulum pendidikan pariwisata dan peningkatan pengelolaan lingkungan hidup.

2. Aspek Penataan Ruang dan Pembiayaan, yaitu penguatan kawasan ekowisata, penyusunan Perda dan revisi RTRW serta perencanaan, pengendalian, pemanfaatan ruang dan bangunan.

3. Aspek Pengembangan Institusi atau Kelembagaan, antara lain peningkatan manajemen dan pelayanan masyarakat serta peningkatan kualitas perencanaan dan pengendalian pembangunan

4. Aspek Pengembangan Produk Wisata dan Usaha Produktif meliputi peningkatan manajemen dan pelayanan masyarakat, peningkatan produktivitas usaha koperasi dan UKM, serta pengembangan agribisnis perkotaan.

5. Aspek Pengembangan Pasar dan Pemasaran seperti sosialisasi dan promosi pengembangan pariwisata.

\section{KESIMPULAN DAN SARAN}

\section{Kesimpulan}

1. Partisipasi masyarakat lokal yang potensial untuk kegiatan ekowisata yaitu melalui kegiatan pengelolaan lingkungan dalam pengolahan sampah yang menarik untuk menjadi wilayah percontohan. Selain itu, kegiatan penanaman pohon juga banyak dilakukan. Tingkat pastisipasi masyarakat di lokasi penelitian berdasarkan Teori Arnstein berada pada tangga pertama Non Participation dan tangga kedua Tokenism, yang bermakna bahwa masyarakat dapat berpendapat seluasluasnya, namun kesempatan untuk mendapatkan suara dalam menentukan kebijakan masih lemah.

2. Aktivitas sosial dan ekonomi yang dapat dikembangkan melalui kegiatan ekowisata di Kota Depok adalah wisata, budidaya tanaman hias dan buah-buahan. Pengembangan tanaman hias berkaitan dengan adanya kecenderungan bahwa komoditas tersebut termasuk unggul di wilayah Kota Depok.

3. Kondisi kebijakan terkait dengan pengembangan ekowisata di Kota Depok saat ini belum optimal, program Pemerintah Kota Depok untuk meningkatkan potensi wisata belum dikenal dengan baik oleh masyarakat Kota Depok. Beberapa aktor yang berperan dalam pengembangan ekowisata ini adalah pemerintah, masyarakat dan swasta. 


\section{Saran}

Berdasarkan hasil analisis pada rencana pengembangan ekowisata di Kota Depok, diperoleh rekomendasi kebijakan yang perlu dipertimbangkan, meliputi:

1. Bagi pihak pemerintah, antara lain kebijakan untuk pengembangan sumberdaya manusia, pemberdayaan masyarakat lokal dalam kegiatan pariwisata, melakukan analisa kelayakan ekonomi dan sosial, penegasan penataan ruang, peningkatan kualitas produk unggulan yang berdaya saing, mengembangkan pola atau teknik promosi dan sosialisasi, serta memberi pinjaman atau insentif kepada masyarakat setempat untuk mengolah sebagian luasan tanah yang terdapat di lokasi ekowisata.

2. Bagi pihak swasta, diharapkan agar dapat menumbuhkan peran aktif pelaku dunia usaha dalam berinvestasi dan berpartisipasi sebagai pelaku pengembang.

3. Bagi masyarakat, diharapkan untuk mendukung program pembangunan mulai dari perencanaan dan ikut terlibat juga dalam pelaksanaan program.

\section{DAFTAR PUSTAKA}

Agus, Fahmudin dan Widianto. 2004. Petunjuk Praktik Konservasi Tanah Pertanian Lahan Kering, World Agroforestry Centre ICRAF Southeast Asia. Bogor.

Arnstein, Sherry R. 1969. A Ladder of Citizen Participation. American Institute of Planners Journal.

Ceballos-Lascurain, H. 1996. Tourism, Ecotourism and Protected Areas. The State of Nature-based Tourism Around the World and Guidelines for its Development. IUCN (International Union for the Conservation of Nature), Gland, Switzerland and Cambridge, UK.
Cooper, C., Fletcher, J., Gilbert, D. Shepherd, R. dan Wanhill, S. 1996. Prinsip Pariwisata dan Praktik. London: Pitman

Eplerwood, Megan, 1999. International EplerWood. Burlington, USA

Falatehan, F. 2007. Teknik Pengambilan Keputusan Aplikasi Analytic Hierarchy Process (AHP) Menggunakan Program Expert Choice 2000. Program Studi Manajemen Pembangunan Daerah. Bogor: Institut Pertanian Bogor

Fandeli, Chafid. dan Mukhlison. 2000, Pengusahaan Ekowisata, Fakultas Kehutanan. Yogyakarta: Universitas Gadjah Mada.

Mulyadi dan S. Nurhayati. 2002. Pengertian Pariwisata. Badan Pengembangan Kebudayaan dan Pariwisata, Pusat Pelatihan dan Pendidikan. Jakarta

Oakley, Peter. and David Marsden. 1984. Approaches to Participation in Rural Development. Geneva: ILO

Rifkin, SB; F Muller; W. Bichman. 1990. Primary Health Care: On Measuring Participation, Social Science and Medicine.

Suwantoro, Gamal. 1997. Dasar-dasar Pariwisata. Yogyakarta: Penerbit ANDI.

[TIES]. 1990. The International Ecotourism Society,Fact Sheet: Global Ecotourism. Washington, DC, USA. http://www.ecotourism.org/

Winarno, Budi. 2007. Kebijakan Publik, Teori dan Proses. Edisi Revisi. Yogyakarta: Penerbit Media Pressindo.

Yoeti, Oka A. 2008. Ekonomi pariwisata: introduksi, informasi, dan aplikasi. Jakarta: Penerbit Buku Kompas.

Yuliandra, Fredinan, 2007, 'Ekowisata Bahari Sebagai Alternatif Pemanfaatan Sumberdaya Pesisir Berbasis Konservasi", Departemen Manajemen Sumberdaya Perairan, Fakultas Perikanan dan Ilmu 
Kelautan. Bogor: Institut Pertanian

Bogor 